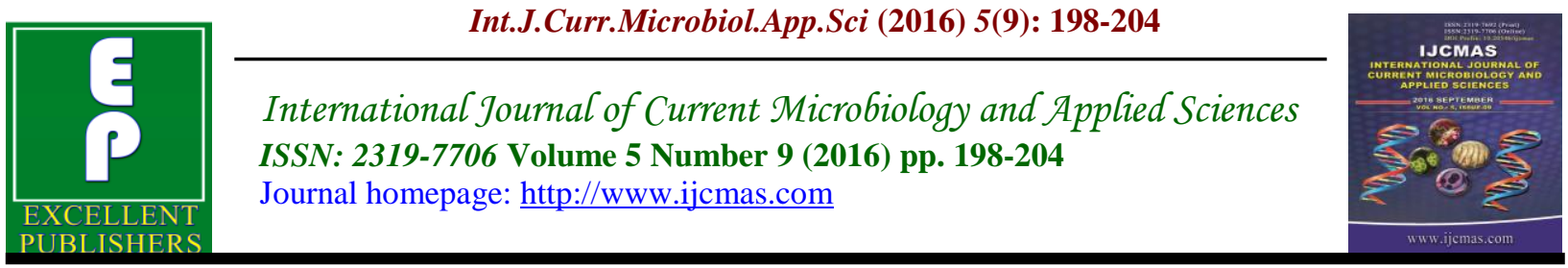

Original Research Article

http://dx.doi.org/10.20546/ijcmas.2016.509.022

\title{
Antibacterial Activity of Methanolic Extract of Medicinal Plant- Murraya paniculata (Linn.) against Xanthomonas citri
}

\author{
Sapan Patel ${ }^{1 *}$ and Ankita Sharma ${ }^{2}$ \\ ${ }^{1}$ School of studies in Botany, Jiwaji University, Gwalior, M.P, India \\ ${ }^{2}$ School of Studies in Microbiology, Jiwaji University, Gwalior, M.P, India \\ *Corresponding author
}

Keywords

Murraya

paniculata,

Xanthomonas citri,

Kanamycin,

antibacterial

activity.

Article Info

Accepted:

13 August 2016

Available Online:

10 September 2016
The present study aimed at evaluating the antibacterial activity of methanolic extract of Murraya paniculata (leaves and stem) against Xanthomonas citri using agar well diffusion method on different concentration. Murraya paniculata commonly known as orange jasmine or honey bush, in Hindi this plant is popular as "Kamini". There are numerous uses of Murraya paniculata in traditional medicine for the treatment of different diseases of plants and animals. In India most of the plant pathogenic diseases were caused by bacteria. In the Gwalior-Chambal division of Madhya Pradesh so many plant diseases are caused by different species of Xanthomonas. In this research work our main aim is to develop the natural bactericides. In this study some effective results have observed by the use of methanolic extract of Murraya paniculata. The results of inhibitory activity of the methanolic plant extract compare with the standard antibiotic Kanamycin. The zone of inhibition of extract of Murraya paniculata at the concentration of 200 $\mu \mathrm{g} / \mathrm{ml}$ was $25 \mathrm{~mm}$ (leaves) and the zone of inhibition of the standard antibiotic Kanamycin was $32 \mathrm{~mm}$. Hence, the result of Murraya paniculata (leaves) is so closer to the standard antibiotic. Therefore, there is a scope to use Murraya paniculata (leaves) extract against Xanthomonas citri as bactericides.

\section{Introduction}

Plant pathogenic microorganisms likebacteria, fungi, viruses cause many serious diseases in plants throughout the world (Vidhyasekaran, 2002). Recently, bacterial pathogens and their control is a serious threat in agricultural practices. Beattie, 2006 has studied that some bacteria are associated with plants are diverse in the habitats they occupy their phylogeny and they affect on plants and environmental health. Different diseases of plants are caused by different genera like - Pseudomonas, Xanthomonas, Xylella, Xylophillus, Acidovorax, Agrobacterium, Erwinia, Pantoea, Ralstonia, Burkholderia, Clavibacter, Streptomyces, Spiroplasma and Phytoplasma (Ellis et al., 2008). Among different genera, Xanthomonas is a very important kind of plant pathogenic bacteria, which is one of the main causal organisms in different diseases in crops, fruits and vegetables in all over the world. It is a 
Gram- negative bacterial genera. Pathovars of Xanthomonas are known to cause disease on several vegetable and crops and are reported to have developed resistance to Kanamycin, Ampicillin, Penicillin and Streptomycin (Weller and Saettler, 1980; Nafade and Verma, 1985; Verma et al., 1989; Rodriguez et al., 1997). Xanthomonas species can cause bacterial spots and blights of leaves, stems and fruits, citrus canker on a wide variety of plant species (Boch et al., 2010). There have been different methods for control of bacterial diseases in plants by the use of different methods like spraying with antibiotics and copper compounds along with pesticides are usually applied. Microorganisms have developed resistance against antibiotics and this has created risk in the treatment of infectious diseases and phytopathogens (Nagumanthri et al., 2012). Bruce, 2010 has studied that synthetic pesticides have provided cost-effective control of pests over the last few decades but have several disadvantages like damage to environment and also provide direct affect to human health as well. However, the development of new pesticides is important towards combating resistant pathogens. The increasing incidence of pesticides resistance is further fueling the need for new generation of pesticides which are natural and ecofriendly (Kavitha \& Satish, 2011). Recently, in plant pathology the great attention is dedicated to search and produce medicinal plant extracts. This is one of the best ways to substitute synthetic pesticides and antibiotics for inhibition of plant pathogens and also provide beneficial effect to environment and living being in the world. Plant based antimicrobials have enormous therapeutic potential as they can serve the purpose with lesser side effects that are often associate with synthetic antimicrobials (Nagumanthri et al., 2012). However, the decade has been witnessed an increase in the investigation of plants as a source of plant and human disease management (Kamaba and Hassan, 2010). In the report of World Health Organization, 2008 medicinal plants that contain biochemical compound can be used for therapeutic purposes or those that synthesize metabolites to produce useful drugs. Murraya paniculata (Linn.), commonly known as orange jasmine or honey bush belongs to the family Rutaceae and is also known as Chalcas exotica, Chalcas paniculata, and Camunium exoticum (Seidemann, 2005). It is distributed throughout the world like- India, Bangladesh, tropical Srilanka to Myanmar, southern China, Taiwan, Thailand and eastwards throughout the Malaysian region to northeastern Australia and Caledonia. $M$. paniculata is commonly used in traditional medicines for the treatment of diarrhea, abdominal pain, stomach ache, dysentery, headache, edema, thrombosis and stasis of blood. Thus, the objective of present study is to determine the antibacterial activity of methanolic extract of leaves and stem of Murraya paniculata against Xanthomonas citri.

\section{Materials and Methods}

\section{Collection of Plant material}

Different parts of plants like leaves and stem were collected from Jiwaji University campus, Gwalior (M.P.), India during the month of February to March 2016.

\section{Preparation of Plant Extract}

Fresh leaves and stem of $M$. paniculata were washed 2-3 times with tap water and subjected to shade drying at room temperature. The dried plant material was powdered using a clean mixer grinder and filled in air tight container and store in a dry 
place on room temperature until analysis (Harborne, 1979).

\section{Methanol Extraction}

The powdered materials of $M$. paniculata were extracted with methanol. During extraction the ratio was taken 1:10 placed into Soxhlet apparatus which run for ten cycles. The duration of each cycle was about 55 minutes. After the completion of ten cycles the color of powdered material was disappeared or light. After extraction the crude extract were evaporated at $40^{\circ} \mathrm{C}$ with the help of Hot plate stirrer. The extracts were collected and stored at $4^{0} \mathrm{C}$ in sterile air tight containers for further analysis (Harborne, 1979).

\section{Antibacterial assay}

Xanthomonas citri (ITCC NO. BN0001) was procured from the Indian Agriculture Research Institute (IARI), Pusa, New-Delhi. The antibacterial activity of methanol extract of leaves and stem of $M$. puniculata was tested by agar well diffusion method (Akpata and Akinrimisi, 1977). The extract of leaves and stem of $M$. puniculata were dissolve in DMSO (Dimethyl Sulphoxide) in a concentration of $100 \mathrm{mg} / \mathrm{ml}$. In this method wells were made in Muller Hinton Agar (MHA) medium using sterile cork borer after the spreading of bacteria. The method is suitable for organisms that grow rapidly overnight at $35-37^{\circ} \mathrm{C}$. The previously inoculated bacterial strain was spread on MHA. After few minute, five wells were made in each Petri plate and loaded with different concentration (40,80, 120, 160 and $200 \mu \mathrm{g} / \mathrm{ml})$. Similar concentration $(40,80$, 120, 160 and $200 \mu \mathrm{g} / \mathrm{ml}$ ) of antibiotic Kanamycin solution was added in another plate for positive control. Plates were incubated at $37^{\circ} \mathrm{C}$ for $24 \mathrm{hrs}$. The zone of inhibition of bacterial growth around each well is measured and the susceptibility is determined. Antibacterial activity was evaluated by measuring zone of inhibition by using Hi-media zone scale.

\section{Results and Discussion}

The antibacterial activity of Methanolic extract of $M$. paniculata was investigated using agar well diffusion method, against Xanthomonas citri at different concentration $(40 \mu \mathrm{g} / \mathrm{ml}, 80 \mu \mathrm{g} / \mathrm{ml}, 120 \mu \mathrm{g} / \mathrm{ml}, 160 \mu \mathrm{g} / \mathrm{ml}$ and $200 \mu \mathrm{g} / \mathrm{ml}$ ) after 24 hours of incubation we observed that the zone of inhibition was shown in Table 1:

\section{Zone of Inhibition (ZOI)}

The antibacterial activity of Methanol extract of $M$. puniculata (leaves) showed the maximum zone of inhibition $25 \mathrm{~mm}$ at the concentration of $200 \mu \mathrm{g} / \mathrm{ml}$ against X.citri followed by $22 \mathrm{~mm}$ at the same concentration of $M$. puniculata (stem), $21 \mathrm{~mm}$ (stem) at $160 \mu \mathrm{g} / \mathrm{ml}, 20 \mathrm{~mm}$ (leaf) at same concentration, $20 \mathrm{~mm}$ (leaf) at 120 $\mu \mathrm{g} / \mathrm{ml}, 16 \mathrm{~mm}$ (stem) at same concentration, $13 \mathrm{~mm}$ (stem) at $80 \mu \mathrm{g} / \mathrm{ml}, 12 \mathrm{~mm}$ at same concentration and $12 \mathrm{~mm}$ (leaf) at $40 \mu \mathrm{g} / \mathrm{ml}$, $10 \mathrm{~mm}$ (stem) at the same concentration of Methanol extract of $M$. puniculata. Highly significant antibacterial activity was observed in M. puniculata (leaf) $25 \mathrm{~mm}$ at the concentration of $200 \mu \mathrm{g} / \mathrm{ml} \mathrm{We}$ have done parallel experiment with Positive control antibiotic Kanamycin which shows significant antibacterial activity against X.citri., which are showed in Table -1 and Graph 2.

Herbal medicines play an important role to cure various plant and animal diseases. Recently the works on plant pathogen by various scientists have been extensively increased throughout the world (Satish et al., 1999; Britto et al., 2011). In this study we 
checked the antibacterial activity of methanolic extract of $M$. paniculata against X.citri. X.citri severely affects many citrus crop and cause big economic impact on farmers throughout the world (Prakash et al., 2012).

Table.1 Antibacterial activity of M. paniculata (Leaf and Stem) against Xanthomonas citri on different concentration compared with positive controls (zone of inhibition in $\mathrm{mm}$ )

\begin{tabular}{|c|c|c|c|c|}
\hline S. No. & Concentration $(\mu \mathrm{g} / \mathrm{ml})$ & Sample & $\begin{array}{l}\text { Methanolic extract } \\
\text { (ZOI in } \mathrm{mm} .)\end{array}$ & $\begin{array}{c}\text { Kanamycin } \\
\text { (ZOI in mm.) }\end{array}$ \\
\hline \multirow[t]{2}{*}{01} & \multirow[t]{2}{*}{40} & Leaf & 12 & \multirow[b]{2}{*}{26} \\
\hline & & Stem & 10 & \\
\hline \multirow[t]{2}{*}{02} & \multirow[t]{2}{*}{80} & Leaf & 12 & \multirow[b]{2}{*}{28} \\
\hline & & Stem & 13 & \\
\hline \multirow[t]{2}{*}{03} & \multirow[t]{2}{*}{120} & Leaf & 20 & \multirow[b]{2}{*}{29} \\
\hline & & Stem & 16 & \\
\hline \multirow[t]{2}{*}{04} & \multirow[t]{2}{*}{160} & Leaf & 20 & \multirow[b]{2}{*}{30} \\
\hline & & Stem & 21 & \\
\hline \multirow[t]{2}{*}{05} & \multirow[t]{2}{*}{200} & Leaf & 25 & \multirow[b]{2}{*}{32} \\
\hline & & Stem & 22 & \\
\hline
\end{tabular}

Zone of Inhibition (ZOI)

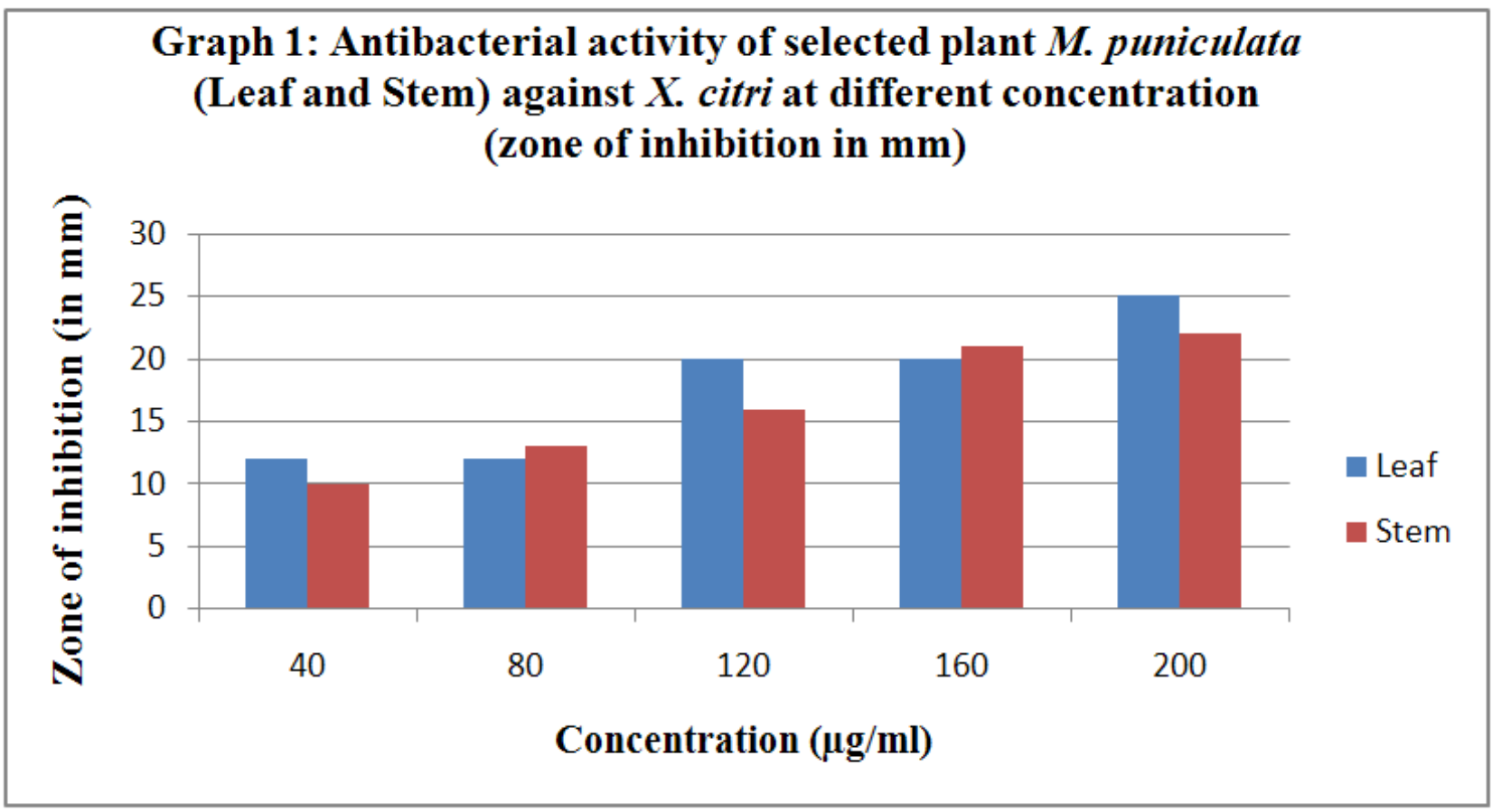




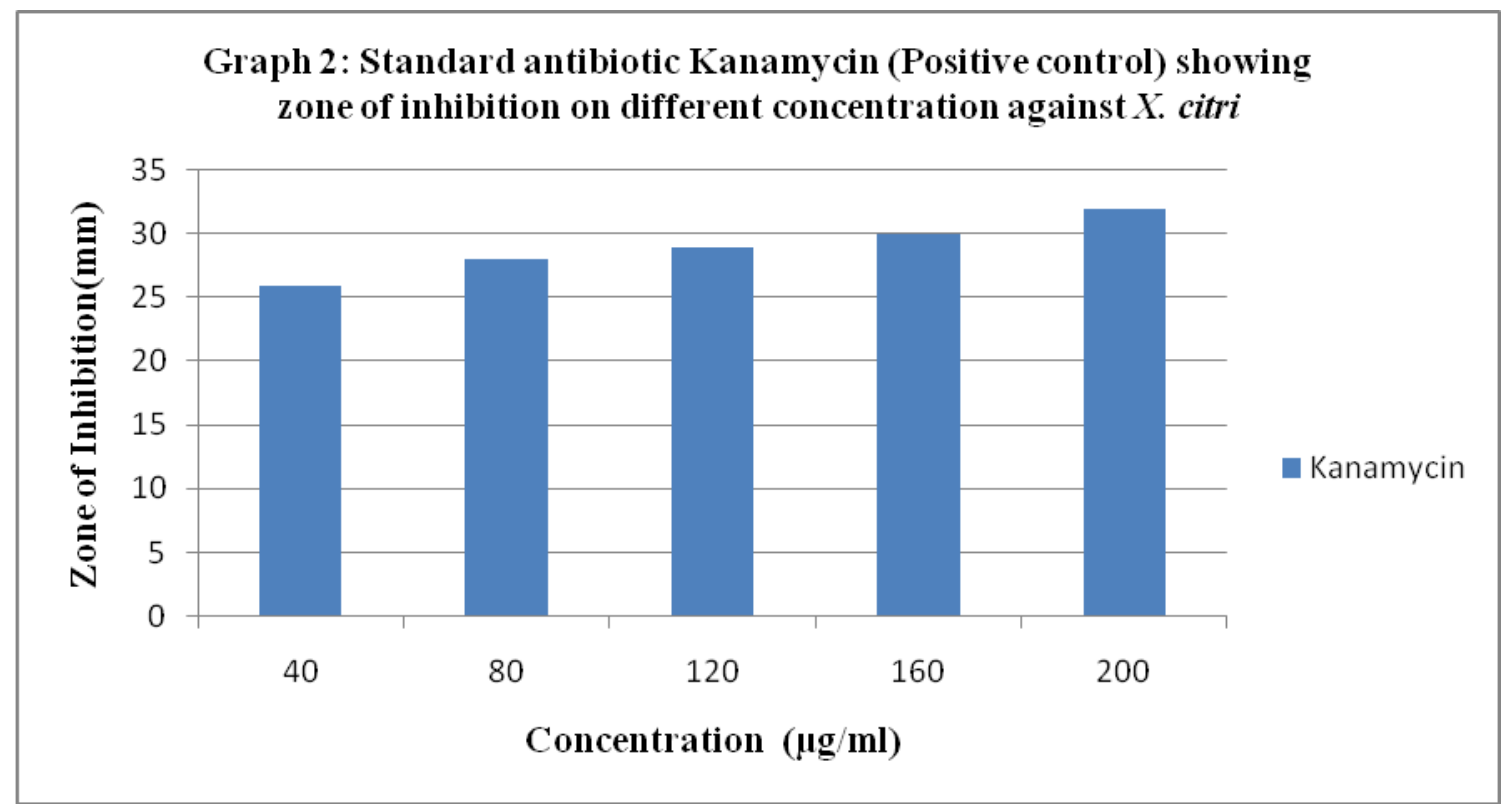

This is an initial step to control X.citri under in-vitro condition. The antibacterial activity of $M$. paniculata( Methanolic extract) showed different results on different level of concentration $(40 \mu \mathrm{g} / \mathrm{ml}, 80 \mu \mathrm{g} / \mathrm{ml}, 120$ $\mu \mathrm{g} / \mathrm{ml}, \quad 160 \mu \mathrm{g} / \mathrm{ml}, 200 \mu \mathrm{g} / \mathrm{ml}$ ) but the maximum zone of inhibition was found on $200 \mu \mathrm{g} / \mathrm{ml}$ that is $25 \mathrm{~mm}$ ( leaves). On the same concentration the positive control Kanamycin gave $30 \mathrm{~mm}$ zone of inhibition. The findings of Leksomboon et al., (2001) have been revealed that $X$. axonopodis pv.citri was inhibited against $H$. subdariffa, $P$. guajava, $S$. pinnata, and $T$. indica reduced the canker incidence varying from $18 \%$ to $52 \%$. Antibacterial activity of vitex negundo against $X$. campestris pv. citri was reported by Devi et al., (2014) and observed that the chloroform and cow extract showed excellent zone of inhibition $14 \mathrm{~mm}$ and $16 \mathrm{~mm}$ respectively. Deshmukh et al., (2014) also worked on X.citri using agar well diffusion method and found the widest zone of inhibition that is $14 \mathrm{~mm}$. Jadhav and Deobhankar (2013) studied that A. sativum, E. officinalis, E. globus and A. indica showed highest antibacterial activity against X.citri. The highest zone of inhibition is $24.4 \mathrm{~mm}$ (E. officinalis). The comparison of the stem of $M$. paniculata and leaf extracts, leaf extracts were effective against tested bacterial strains. The present study is an important attempt to develop plant based bactericides which are ecofriendly or beneficial to the management of $X$. cirri.

\section{Acknowledgements}

Authors are thankful to School of Studies in Microbiology, Jiwaji University, Gwalior (M.P.) for providing necessary facilities during the tenure of research work.

\section{References}

Akpata, E.S., and Akinrinmisi, E.O. 1977. Antibacterial activity of extracts of some African chewing sticks. Hos. Surg, 44: 717-722.

Aziz, S.S.S.A., M.A. Sukari, M. Rahmani, M. Kitajima, N. Aimi, Ahpandi, N.J. 2010. Coumarins from Murraya paniculata (Rutaceae). Malaysian J. Anal. Sci., 14: 1-5.14.

Beattie, G.A. 2006. Plant- Associated Bacteria: Survey, molecular phylogeny, genomics and recent advances, Samuel S. Gnanamanickam 
editor, Springer Netherland. 1-56.

Boch, J., and Bonas, U. 2010. "XanthomonasAvrBs3 Family-Type III Effectors: Discovery and Function". Annual Rev. Phytopathol., 48: 419-36.

Bruce, T.J.A. 2010. GM as a route for delivery of sustainable crop protection. J. Experimental Bot., 63(2): 537-541.

Deshmukh, K.P., Deshmukh, Y.D. 2014. Antibacterial activity of (Syzygium Aromaticum) Clove, (Zingiber Officinale) Ginger, (Allium Cepa) Onion, (Allium Sativum) Garlic against three human and two plant pathogens. Int. J. Green and Herbal Chem., 3(1): 204-210.

Devi, N.V., Kumar, S.P. 2014. Evaluation of the Antibacterial Potential, Preliminary Phytochemical screening of Plant against Plant Pathogen. Sci. Alert, 8: 92-101.

Ellis, S.D., M.J. Boehm, and Coplin, D. 2008. Bacterial diseases of plants. $6^{\text {th }}$ Fact sheet Agriculture and Natural Resources, The Ohio State University. Pp. 401. Pp. 06-2-4.

Harborne, J.B. 1973. Phytochemical methods. London. Chapman and Hall. Ltd. Pp- 49188.

Jadhav, M.D., and Deobhankar, K.P. 2013. Antibacterial activity of Medicinal plant's against Xanthomonas citri. Int. J. Adv. Biotechnol. Res., 4(3): 315318.

Kamba, A.S., Hassan, L.G. 2010. Phytochemical and Microbial Screening of Parkinsonia Aculeata L. Leaves. Int. J. Drug and Develop. Res., 2(1): 1-7.

Kavitha, H.U., and Satish, S. 2011. Ecofriendly management of plant pathogens by some medicinal plant extracts. J. Appl. Toxicity, 7(2): $449-461$.
Kinoshita, T., and Firman, K. 1996. Highly oxygenated flavonoids from Murraya paniculata. Phytochem., 42: 1207-1210.

Leksomboon, C., N. Thaveechai, and Kositaratana, W. 2001. Potential of Plant Extracts for controlling Citrus Canker of Lime. Kasetsart J., (Nat. Sci.). 35: 392-396.

Nafade, S.D., and Verma, J.P. 1985. Drug resistant mutants of Xanthomonas campestris pv. malvacearum. Indian Phytopathol., 38: 77-79.

Nagumanthri, V., S. Rahiman, Tantry. B.A, P. Nissankararao, Phani, K.M. 2012. In vitro antimicrobial activity of Acacia nilotica, Zizipus mauritiana, Bauhinia variegate and Lantana camara against some clinical isolated strains. Iran J. Sci. Technol., A2: 213217.

Rodriguez, H., L. Aguilar, Lao, M. 1997. Variation in Xanthan production by antibiotic resistant mutants of Xanthomonas campestris. Appl. Microbiol. Biotechnol., 48: 626-629.

Saeed, S., S. Shah, R. Mehmood, and Malik, A. 2011. Paniculacin, a new coumarin derivative from Murraya paniculata. J. Asian Natural Products Res., 13: 724-727.

Sawangjaroen, N., S. Phongpaichit, S. Subhadhirasakul, M. Visutthi, Srisuwan, N. 2006. Thammapalerd, N. The anti-amoebic activity of some medicinal plants used by AIDS patients in southern Thailand. Parasitol. Res., 98: 588-592.

Seidemann, J. 2005. World Spice Plants: Economic Usage, Botany, Taxonomy; Springer. Berlin, Germany.

Sharker, S.M., I.J. Shahid, Hasanuzzaman, M. 2009. Antinociceptive and bioactivity of leaves of Murraya paniculata (L.) Jack, Rutaceae. Brazilian J. Pharmacognosy, 19: 746- 
748.

Sukari, M.A., S.S.S. Azziz, M. Rahmani, A.M. Ali, N. Aimi, Kitajima, M. 2003. Polysubstituted flavonoids from the leaves of Murraya paniculata (Rutaceae). Natural Product Sci., 9: $56-59$.

Weller, W.M., and Saettler, A.W. 1980. Colonization and distribution of Xanthomonas phaseoli and Xanthomonas phaseoli var. fusans in field-grown Navy beans. Phytopathol., 70: 500-506.

World Health Organization. 2008. Traditional medicine. http://www.who.int/mediacentre/ factsheets/fs134/en/

Zhang, Y., Li, J.S., X. Zhou, Tu, P.F. 2010. Polymethoxylated flavonoids from the leaves of Murraya paniculata. Chineese Pharmaceutical J., 45: 1139-1141.

\section{How to cite this article:}

Sapan Patel and Ankita Sharma. 2016. Antibacterial Activity of Methanolic Extract of Medicinal Plant- Murraya paniculata (Linn.) against Xanthomonas citri. Int.J.Curr.Microbiol.App.Sci. 5(9): 198-204. doi: http://dx.doi.org/10.20546/ijcmas.2016.509.022 